\title{
The Influence of Virtual Chemistry Laboratory Media on Students' Understanding of Submicroscopic Level and Student Activity Grade XI
}

\author{
Yunia Rizki \\ Department of Chemistry Education \\ Universitas Negeri Medan \\ Medan, Indonesia \\ *Corresponding authors: \\ yuniarizki1@gmail.com
}

\author{
Murniaty Simorangkir \\ Department of Chemistry Education \\ Universitas Negeri Medan \\ Medan, Indonesia
}

\author{
Eddyanto \\ Department of Chemistry Education \\ Universitas Negeri Medan \\ Medan, Indonesia
}

\begin{abstract}
The purpose of this study was to analyze the influence of virtual chemistry laboratory on students understanding of submicroscopic level and student activity in solubility and solubility product topic. This research was descriptive analysis. This research was conducted in State Senior High School 1 Binjai. Sample of this research was 64 students that divided into two classes as experiment class and control class. Experiment class was learned by using virtual chemistry laboratory while control class was learned without using virtual chemistry laboratory. In analyzing student understanding of submicroscopic level,students were given a written test in the form of worksheet (essay test) consist of 10 questions. Student activity were observed during teaching and learning activity by using observation sheet. The result obtained that (1) Students understanding of submicroscopic level that is learned by using virtual chemistry laboratory media is higher than the students understanding of submicroscopic level that is learned without using virtual chemistry laboratory (2) Student activity that is learned by using virtual chemistry laboratory media is more active than the student activity that is learned without using virtual chemistry laboratory.
\end{abstract}

Keywords-student understanding of submicroscopic level, student activity, virtual chemistry laboratory

\section{INTRODUCTION}

Chemistry is a science that studies the structure, composition and properties of substances. Understanding chemistry includes the ability to think on three levels: the macroscopic level, the symbolic level, and the level of particles sub-microscopic level. Students have the most difficulty when trying to understand the sub-microscopic level because it is outside their range of experience [1]. In order to make the better understanding about the sub-microscopic level, students should do experiments in laboratory.

Laboratories are important components of chemistry education. In laboratory applications, students realize practical applications of theoretical knowledge and also they develop their inquiry and scientific processing skills [2].
However, based on the data collected by researcher from 7 State Senior High School (SSHS) in Binjai showed that most of laboratory experiment activity of chemistry courses were missing because of some factors such as absence of chemistry labs, sharing laboratory with physics, chemistry and biology courses, lack of materials and equipments, lack of time, lack of materials, cost of equipments, incapableness of teachers using laboratory effectively and their negative attitudes towards laboratory applications. Besides, the activity process was not supported by the practical guidance book. Teachers do the experiment activity based on the creativity findings from internet browsing. Then problems in activity of laboratory experiment can be overcome by using interactive virtual chemistry laboratory.

Computer assisted laboratory applications are alternatives for educators to cope with the mentioned limitations of traditional laboratories. A computerized laboratory experiment is an efficient tool to aid understanding of topics developed in the classroom and in the laboratory [3].

Since the real experiment allows teachers and students to reach the desired goals, a virtual experiment could be useful for better understanding of the theoretical information and takes student attention to the techniques used to perform the measurements. Also, simulation experiments give students the opportunity to learn in their own ways. With the help of simulation experiments, students learn the proper usage of the equipments. Moreover, it is possible to organize virtual experiments which cannot usually be done in the laboratory (i. e., with harmful or dangerous chemicals) and the simulation of experiments that would require too many hours or expensive instruments [4].

The use of a virtual laboratory can affect the formation of mental models at the submicroscopic level. These dynamic models and animations, which are enabled by a virtual laboratory, when compared with the static sub-micro presentations, proved to be more appropriate for the understanding of chemical concepts [5]. Virtual Laboratory can be an effective tool to help students develop their 
familiarity with the laboratory environment prior to their laboratory sessions [6].

\section{LITERATURE}

\section{A. Learning Media}

Media are the means for transmitting or delivering messages and in teaching and learning perspective delivering content to the learners, to achieve effective instruction. Instructional Technology/media for learning-teaching process provide with the tools to engage learners powerfully in the learning process. It is greatly enhanced the effectiveness of communication. If it is properly designed, skillfully produced and effectively used, it will have great influence on teaching and learning because it could save time, increase interest,hold attention, clarify ideas, reinforce concepts, add tone, prove a point and aid memory [7].

\section{B. Learning Chemistry Concept}

In chemistry and natural sciences in general, the experimental and laboratory work is one of the most effective methods for acquiring knowledge. The detection of concept world of matter, phenomena and processes are characteristic for chemistry at the macroscopic level. For interpreting and forecasting we must use the language of the submicroscopic world. While learning chemistry it is important that students understand and can connect concepts on all three conceptual levels (macroscopic, submicroscopic and symbolic) which are difficult for many of them. The gap between the three conceptual levels can be, to the great extent, overcome by the use of visualization elements [8].

\section{Information and CommunicationTechnology ICT and Chemistry}

The use of computers in science subjects, particularly chemistry, has some specific advantages. Cognitive psychologists assume that the understanding of chemistry includes the ability to think on three levels: the macroscopic level, the symbolic level and the level of particles [9]. Students have the most difficulties in understanding the submicroscopic level because it reaches beyond their experience. In these cases the interactive multimedia can be used as an effective tool. Multimedia demonstration of experiments must not replace other methods of work in teaching chemistry. It helps students understand higher cognitive levels of analysis, synthesis and evaluation [10]. The use of multimedia assisted for teaching chemistry improves teaching because it allows the integration of the three levels of understanding of chemistry, visualization and simulation of processes.

\section{Virtual Chemistry Laboratory}

The virtual laboratory is an interactive environment for creating and conducting simulated experiments: a playground for experimentation. The Virtual Laboratory empowers students to create information on the internet by collecting it from the physical world. Remote computer access to laboratory instruments allows students to conduct actual experiments at any time and from any location. This technology greatly enhances the flexibility of laboratory education, and introduces students to the new paradigm of remote experimentation [11].

\section{E. Understanding of Submicroscopic Level}

Three levels in understanding chemistry concept are symbolic, macroscopic and submicroscopic. Symbolic represents structural formula, empirical formula and chemical equation. Macroscopic represents mass, $\mathrm{pH}$, density, temperature and osmotic pressure. Submicroscopic level represent phenomenon of atoms, ions, electrons, molecules and particles movement [12]

\section{F. StudentsActivity}

Student's activity is the involvement of students in the form of attitudes, thoughts, attention in learning activities to support the success of the learning process and benefit from these activities [13]

\section{RESEARCH METHOD}

This research wasdescriptive analysis. Descriptive analysis method was used to analyze student understanding of submicroscopic level and student activity. This research was conducted in State Senior High School 1 Binjai. Sample of this research were 64 students that divided into two classes as experiment class and control class. Experiment class was learned by using virtual chemistry laboratory while control class was learned without using virtual chemistry laboratory. The sample was chosen by purposive sampling technique. The virtual chemistry laboratorythat was used in this study had been developed by researchers and validated by expert validator. The media can be applied by using Adobe Flash. The topic of material for learning media was solubility and solubility product. Research procedures were summarized in Fig. 3.1 


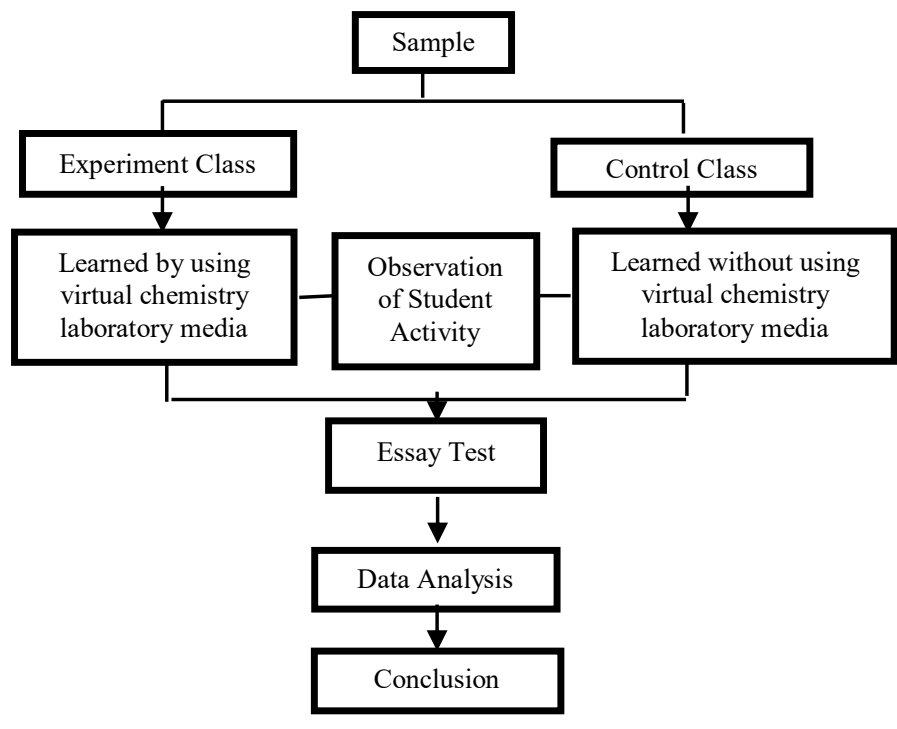

Fig 3.1. Research Procedures

In analyzing student understanding of submicroscopic level, students were given a written test in the form of worksheet (essay test) consist of 10 questions.Students' understanding of submicroscopic level was firstly tested of the normality and homogeneity. To test the normality used by Statistical Package For The Social Sciences (SPSS) 20.0 withKolmogorov-Smirnof, the data can be stated as normally distributed when the significant probability value (2-sided) $>$ 0.05 significance level [14]. Homogeneity test is performed with Levene test, the data are homogeneous if significant probability value (2-tailed) $>0.05$ significance level [15]. Data obtained from the assessment results of students' understanding on submicroscopic level in solubility and solubility product topic wascalculatedbyusing following formula:

Then the result of students' understanding of submicroscopic level was analyzed descriptively using category:

TABLE 3.1 Category of Students' Understanding of Submicroscopic Level

\begin{tabular}{|c|c|}
\hline Range & Category \\
\hline $91-100$ & Very High \\
\hline $81-90$ & High \\
\hline $71-80$ & Medium \\
\hline $61-70$ & Enough \\
\hline $51-60$ & Low \\
\hline$<50$ & Very Low \\
\hline
\end{tabular}

Student activity was observed during teaching and learning activity by using observation sheet.Scores given wereas follows: Score 3: if three descriptors appear; Score 2: if two descriptors appear; Score 1: if one descriptor appear.The value of student activity was calculated by formula:

Then the result of student activity observation was analyzed descriptively using category:

TABLE 3.2.Category of Student Activity

\begin{tabular}{|c|c|}
\hline Score & Category \\
\hline $81-100$ & Very Active \\
\hline $61-80$ & Active \\
\hline $41-60$ & Active Enough \\
\hline $21-40$ & Less Active \\
\hline $0-20$ & Not Active \\
\hline
\end{tabular}

\section{Hypothesis Test}

The hypothesis Test was used to analyze the different result for students' understanding of submicroscopic level of the two groups. Hypothesis test was performed by usingIndependent Sample T-Test on SPSS 21 program.

$$
\begin{aligned}
& \text { 1. } \mathrm{Ha}=\mu_{1} \geq \mu_{2} \\
& \text { 2. Ho }=\mu_{1} \leq \mu_{2}
\end{aligned}
$$

\section{RESULT AND DISCUSSION}

\section{Research Result}

In analyzing student understanding of submicroscopic level, students were given a written test in the form of worksheet (essay test) consist of 10 questions. Each question represents indicator that measure student understanding the chemistry concept at submicroscopic level. Data obtained the average value in experiment class and control class were 85.65 and 78.13 respectively, the lowest average value of students understanding of submicroscopic level was in control class and the highest average value of students understanding of submicroscopic level was in experiment class. The different criteria for student understanding of submicroscopic level of the two groups can be seen in Table 4.1

TABLE 4.1.Criteria of Students' Understanding ofSubmicroscopic Level in Experiment andControlClass

\begin{tabular}{|c|c|c|}
\hline Group & The Average Value & Criteria \\
\hline Experiment Class & 85.65 & High \\
\hline Control Class & 78.13 & Medium \\
\hline
\end{tabular}


Based on Table 4.1 can be assumed that student understanding of submicroscopic level in experiment class has the high criteria while in control class has medium criteria.

Student activity was observed during teaching and learning activity by using observation sheet. There were some aspects to be observed such as visual activities, oral activities, listening activities, writing activities and emotionalactivities. The average value of students' activity was seen from several aspect of assessment for experimental and control class were 91.78 and 81.93 respectively. This means the student in experimental class wasmore active than in control class with the criteria can be seen in the Table 4.2.

TABLE 4.2. Criteria of Student Activity in ExperimentandControl Class

\begin{tabular}{|c|c|c|}
\hline Group & The Average Value & Criteria \\
\hline Experiment Class & 91.78 & Very Active \\
\hline Control Class & 81.93 & Active \\
\hline
\end{tabular}

Based on the criteria of student activity obtained that student in experiment class was very active while student in control class was active.

\section{Hypothesis Test}

In analyzing the differences student understanding ofsubmicroscopic level in experiment class and control class were analyzed by Independent Sample T-Test as shown in Table 4.3, Ha test criteria accepted if significance value $<$ 0.05 .

\begin{tabular}{|c|c|c|c|c|c|c|c|c|c|c|}
\hline \multicolumn{11}{|c|}{ Independent Sample Test } \\
\hline & & \multicolumn{2}{|c|}{$\begin{array}{l}\text { Levene } \\
\text { Test for } \\
\text { Equality } \\
\quad \text { of } \\
\text { Variance }\end{array}$} & \multicolumn{7}{|c|}{ t-test for equality of Means } \\
\hline & & \multirow[t]{2}{*}{$\mathrm{F}$} & \multirow[t]{2}{*}{ Sig } & \multirow[t]{2}{*}{$\mathrm{t}$} & \multirow[t]{2}{*}{ df } & \multirow[t]{2}{*}{$\begin{array}{l}\text { Sig } \\
(2- \\
\text { tail } \\
\text { ed) }\end{array}$} & \multirow{2}{*}{$\begin{array}{l}\text { Me } \\
\text { an } \\
\text { Dif } \\
\text { fer } \\
\text { en } \\
\text { ce }\end{array}$} & \multirow[t]{2}{*}{$\begin{array}{l}\text { Std } \\
\text { Error } \\
\text { Differe } \\
\text { nce }\end{array}$} & \multicolumn{2}{|c|}{$\begin{array}{l}95 \% \\
\text { confidence } \\
\text { Interval of } \\
\text { difference }\end{array}$} \\
\hline & & & & & & & & & $\begin{array}{l}\text { Lowe } \\
r\end{array}$ & $\begin{array}{l}\text { Up } \\
\text { per }\end{array}$ \\
\hline \multirow[t]{2}{*}{$\begin{array}{l}\text { Valu } \\
\text { e }\end{array}$} & $\begin{array}{l}\text { Equal } \\
\text { Variance } \\
\text { assumed }\end{array}$ & $\begin{array}{l}13 \\
3\end{array}$ & $\begin{array}{l}71 \\
6\end{array}$ & $\begin{array}{l}3 \\
9 \\
9\end{array}$ & 62 & $\begin{array}{l}\text {,00 } \\
1\end{array}$ & $\begin{array}{l}6,7 \\
2\end{array}$ & 1,69 & $\begin{array}{l}3,32 \\
3\end{array}$ & $\begin{array}{l}10 \\
11 \\
3\end{array}$ \\
\hline & $\begin{array}{l}\text { Equal } \\
\text { Variance } \\
\text { not } \\
\text { assumed }\end{array}$ & & & $\begin{array}{l}3 \\
9\end{array}$ & 59 & $\begin{array}{l}\text {,00 } \\
1\end{array}$ & $\begin{array}{l}6,7 \\
2\end{array}$ & 1,69 & $\begin{array}{l}3,32 \\
0\end{array}$ & $\begin{array}{l}10 \\
11 \\
6\end{array}$ \\
\hline
\end{tabular}

Based on Table 4.3 student understanding of submicroscopic level obtained significant value $0.001<a$ (0.05) which means $\mathrm{Ha}$ is accepted, it can be assumed that student understanding of submicroscopic level that was learned by using virtual chemistry laboratory media is higher than student understanding of submicroscopic level that was learned without using virtual chemistry laboratory media.

\section{Result Discussion}

This research was aimed to analyze the influence of virtual chemistry laboratory media on student understanding of submicroscopic level and student activity in grade XI.In analyzing student understanding of submicroscopic level, both of experiment and control class were given the essay test. The average value of students' understanding of submicroscopic level in experiment and control class was 85.65 and 78.13 respectively. It means the students' understanding of submicroscopic level in experimental class is higher than in control class. Relevance study concludes that the use of a virtual laboratory can affect the formation of mental models at thesubmicroscopic level. These dynamic models and animations, which are enabled by a virtual laboratory, when compared with the static sub-micro presentations, proved to be more appropriate for the understanding of chemical concepts [16].

In analyzing student activity, the students were observed with some categories such as visual activity, oral activity, emotional activity, writing activity and listening activity. The average value of student activity in experimental and control class were 91.78 and 81.93 respectively. From the result obtained that the student activity in experimental class was more active than in control class. Relevance study showed that virtual laboratory applications made positive effects on students' achievements and attitudes when compared to traditional teaching methods [17].

These results indicate that virtual chemistry laboratory that developed can be used as media in chemistry learning on solubility and solubility product topic. The virtual chemistry laboratory that developed contains several experiments from each subtopic with submicroscopic explanation that cannot be visualized in laboratory experiments. In addition there are also some videos that explained about the experiment material and examples of calculations for discussion. So, learning by this virtual chemistry laboratory will make students become more active, enthusiastic and focused on what they learn so that can improve students' achievement and better understand the chemical concepts especially on solubility and solubility product at submicroscopic levels.

\section{CONCLUSION}

Based on the research results and discussion, it can beconcluded that : (1) Students understanding of submicroscopic level that is learned by using virtual chemistry laboratory media is higher than the students' understanding of submicroscopic level that is learned without using virtual chemistry laboratory (2) Student activity that is learned by using virtual chemistry laboratory media is more active than learned without using virtual chemistry laboratory media in visual activity, oral activity, emotional activity, writing activity and listening activity. 


\section{ACKNOWLEDGMENT}

This research was supported by thesis supervisor Dr. MurniatySimorangkir, M. S. and Eddyanto, Ph.D that have given the suggestions in order to complete this research.

\section{REFERENCES}

[1] Herga,N. R., Cagran, B., and Dinevski, D, "Virtual Laboratory in the Role of Dynamic Visualisation for Better Understanding of Chemistry in Primary School",Eurasia Journal of Mathematics, Science \& Technology Education, 12(3), pp. 593-608, 2016

[2] Bayrak, C., Ozturk, F.O., Alsan, E. U, A Simulation on Teaching Volhard Method, Turkish Online Journal of Distance Education, 10(3), pp.105-116, 2009

[3] Martinez-Jimenez, P., Pontes-Pedrajas, A., Polo, J., and ClimentBellido, M. S, Learning in Chemistry with Virtual Laboratories, Journal of Chemical Education, 80(3),pp. 346-352, 2003

[4] Belletti, A., Borromei, R. and Ingletto, G, Teaching Physical Chemistry Experiments with a Computer Simulation by LabVIEW. Journal of Chemical Education, 83(9), pp. 1353-1355, 2006

[5] Herga,N. R., la ar, Sa a A., and Dinevski, D Dynamic Visualization in the Virtual Laboratory Enhances the Fundamental Understanding of Chemical Concept, Journal of Baltic Science Education, 14(3), pp. 351-365, 2015

[6] Dalgarno, B., Bishop, Andrea., Adlong, William., and Bedgood, D. R., Effectiveness of a Virtual Laboratory as a Preparatory Resource for Distance Education Chemistry Students, Journal of Computers \& Education, 53(3), pp. 853-865, 2009

[7] Mohan, T., McGregor, H., and Strano, Z., "Communicating! : Theory and Practice", Sydney, Harcourt Brace Jovanovich, 1992

[8] Vrtacnik, M., Ferk, Vesna., Fir, Mojca., Dolnicar, Danica., and Vesna Renic, "Dynamic visualization of science concepts with experiments and models", Ljubljana, University of Ljubljana, 2003

[9] Johnstone, A. H., Why is science difficult to learn: Things are seldom what they seem. Journal of Computer Assisted Learning, 7(2), pp. 75-83, 1991

[10] Kirscher, P. \& Huisman, P., Dry Laboratories in Science Education : Computer-based Practical Work. International Journal of Science Education, 20 (6), pp. 665-682, 1998

[11] Zhao, Li, "Virtual Lab: An Investigation in to The Future of The Teaching Labs “, Birmingham, University of Birmingham, 2015

[12] D. F. Treagust, G. Chittleborough, T. L. Mamiala, "The Role of Submicroscopic and Symbolic Representations in Chemical Explanations, International Journal of Science Education, 25, pp $1353-1368,2003$

[13] A.M., Sardiman, "Interaksi dan Motivasi Belajar Mengajar", Jakarta, PT Rajagrafindo, 2011

[14] S. Saragih, "Aplikasi SPSS Dalam Statistik Penelitian Pendidikan, Medan, Perdana Mulya Sarana, 2015

[15] S. Arikunto, Prosedur Penelitian Suatu Pendekatan Praktik, Jakarta, Rineka Cipta, 2006

[16] Herga, N. Rizman and Dinevski, Dejan, "Virtual Laboratory in Chemistry Experimental Study of Understanding, Reproduction and Application of Acquired Knowledge of Subject's Chemical Content" Journal of Organizacija, 45(3), pp. 108-116, 2012

[17] Tuysuz, C. "The Effect of the Virtual Laboratory on Students'Achievementand Attitude in Chemistry",International Online Journal of Educational Sciences, 2(1), pp. 37-53, 2010 